\title{
UTILIZATION OF ULTRAFILTERED MILK PERMEATE AS WATER SUBSTITUTE IN MANGO DRINK FORTIFIED WITH PUMPKIN CUBES EN ROUTE TO INNOVATE A FUNCTIONAL DRINK
}

\author{
Marwa I. Eid”, Fayed A.E., Khallaf M.F. and Abo El-Naga M.Y.
}

Food Sci. Dept., Fac. of Agric., Ain Shams Univ., P.O. Box 68, Hadayek Shobra11241, Cairo, Egypt

${ }^{*}$ Corresponding author: marwaibrahim910@gmail.com

Received 4 December, 2019

Accepted 19 January, 2020

\section{ABSTRACT}

This study aimed to annexation such impressive health benefits possessed of pumpkin to mango drink in addition to a rich source of the essential electrolytes, namely UF- milk permeate en route to innovate a functional drink.

To achieve this purpose, mango drink based on $14 \%$ fresh mango pulp, per se, and $12 \%$ sucrose was made (the control). Mango pulp was replaced with cooked (at $90^{\circ} \mathrm{C}$ for $5 \mathrm{~min}$ ) pumpkin cubes (CPC) at the level of 5,10 or $15 \%(\mathrm{~W} / \mathrm{W})$. Then $0.2 \% \mathrm{CMC}, 0.015 \% \mathrm{CaCl}_{2}$ and $73.785 \%$ tap water were added for each one and well mixed. On the other hand, the mango pulp replaced with $10 \%$ CPC was chosen as a control in next study, where the water was replaced with UF- milk permeate (UFMP) at the level of 25,50 or $75 \%$ and well mixed. All drinks were heat treated at $90^{\circ} \mathrm{C}$ for 5 min, filled into Pyrex glass bottles, air tightly closed, and cooled to ca $4^{\circ} \mathrm{C}$.

The obtained results indicated that, separately, CPC composed of higher moisture and total nitrogen contents and lower carbohydrates content than mango pulp. Therefore, the mango pulp replacement with CPC in the drink was associated with significant increments in the total solids content as well as $\mathrm{pH}$ value and decrements in the moisture, acidity and total as well as reducing sugars contents. Organoleptically, the mango drink of $10 \%$ CPC possessed scores as high as the control towards the color as well as overall acceptance and came in the second order versus the control towards the consistency and taste criteria. Therefore, this formula was chosen to expose to the experiment of utilization of UFMP instead of water in the drink making. The concerned results confirmed that, significant increments in drink total solids, ash, total as well as reducing sugars contents and $\mathrm{pH}$ value, while both moisture and acidity contents of drink reduced by water replacement with UFMP. Sensory, the drink of $75 \%$ UFMP gained the highest scores in all criteria assessed being better than the control in both consistency and taste attributes. Finally, the forgoing results led satisfactory to conclude that, it could successfully made a drink that meets the intended health purposes based on the substitution of $10 \%$ of mango pulp with cooked cubes of pumpkin of many impressive health benefits as well as the utilization of UF milk permeate as a source of the essential electrolytes instead of $75 \%$ of required water en route to innovate a functional drink.

Keywords: Total solids and sugars; Acidity; Ash; Sensory attributes; Functional drink

\section{INTRODUCTION}

Although not widely known to consumers in general, the difference between juice, nectar and still drink is related to the content of fruit juice present in the packaged beverage. Worldwide, products labeled as "juice" must contain $100 \%$ fresh fruit, therefore these are pure products with no preservatives or sweeteners and no artificial colors, and may or may not contain pulp of the fruit itself. In this category, there is a division between "Reconstituted Juices," which are basically concentrated from three to six times at the juice concentrate factories where they are produced, and subsequently diluted with potable drinking water at a bottling plant, returning the juice to its original condition (in terms of concentration of soluble solids in 
water) at the time of bottling, before being distributed to consumers. Another division of the juice category is "Not-From-Concentrate," commonly known as NFC, which only undergoes a slight pasteurization process.

In the still drink category, the fruit juice content in the packaged beverage is less than $25 \%$, and in many countries only 3 to $5 \%$ (for example, China). These beverages contain a larger quantity of additives, making them a product of lesser value, representing a gateway for the consumption of industrialized still drinks for lower income populations (Neves et al 2011).

There's a big difference between a 'fruit juice' and a 'fruit drink'. If it says 'fruit juice', it must contain undiluted fruit juice. This can have up to $4 \%$ added sugar. If it says 'fruit drink', it must contain at least $5 \%$ fruit juice. But in Egypt, it must contain at least $10 \%$ fruit juice (EOSQ, 2017).

The beverage market represents a large and growing industry within which there are several categories. Electrolytes or sports beverages are designed to deliver rehydration, and they fall into the functional beverage category. Functional beverages offer some types of health benefit, and this category is a rapidly growing sector of the beverage market. The still drink market, which includes functional beverages, grows at an annual rate of $7 \%$, doubles that of carbonated counterparts and encompasses a wide array of beverages (Williams, 2001). Thirst- quenching is a consumer term that may potentially be applied to any beverage (McEwan and Colwill, 1996).

Ultrafiltration (UF) of milk or whey produces a large quantity of permeate as by-product. Permeate is a source of high quality vitamins and minerals that are important to the human health. Where, it is a good source of the essential electrolytes such as calcium, potassium, sodium, magnesium and phosphorus those may be taken as sports drinks after normal or vigorous exercise to replace these ions lost due to effort (Abd El-Khair, 2009 and Hattem et al 2011). Permeate is rich in minerals not found in substitute ingredients and enhances the overall nutritional content of a food product (Fitzpatrick et al 2001).

From this point, some trials were carried out for utilizing permeate $(P)$ ultrafiltered whether from milk (M) or whey (W). Where, MP was mixed with fruit homogenate (strawberry or mango) at ratio of $3: 1(\mathrm{v} / \mathrm{w})$. It was reported that, both drinks were sensory accepted (Hattem et al 2011). Likewise, $500 \mathrm{ml}$ MP beverages fortified with $240 \mathrm{~g}$ lemon as well as $300 \mathrm{~g}$ guava could be recommended as new acceptable functional products (Rizk, 2016). Early, Beucler et al (2005) found that, drinks made using not more than 25 or $50 \%$ of either enzymatically hydrolyzed lactase or unhydrolyzed WP were similar to the commercial beverages in visual and flavor properties. They confirmed also that, drinks made with WP were higher in electrolytes ( $\mathrm{Na}, \mathrm{K}, \mathrm{Zn}, \mathrm{Mg}, \mathrm{P}$ ) content compared with a commercial sports beverage. Beverage incorporation represents a value-added utilization for low levels of WP.

On the other hand, pumpkin refers to Cucurbita pepo, an orange type of winter squash. While commonly viewed as a vegetable, pumpkin is scientifically a fruit, as it contains seeds. Beyond its delicious taste, pumpkin is nutritious and linked to many impressive health benefits (Gong et al 2012). Where, pumpkin is high in vitamins and minerals, while being low in calories. It's also a great source of antioxidants, alpha-carotene and beta-carotene, (provitamin A) carotenoid components those convert in the body into vitamin $A$, with which lutein and zeaxanthin presented also in high levels may protect eyes against sight loss, which becomes more common with age (Wang et al 2011; 2014 and Eisenhauer et al 2017) and can help keep the skin strong and healthy; i.e. acts as a natural sunblock (Roberts et al 2009; Stahl and Sies, 2012 and Pullar et al 2017). Pumpkin contains the beta-cryptoxanthin and many others, which may protect cells against damage by free radicals (Johnson, 2002 and Khansari et al 2009). Carotenoids, those function as antioxidants. These compounds are linked to lower risks of stomach, throat, pancreas and breast cancers (Dreher and Junod, 1996; Hu et al 2012; Zhou et al 2016) .Besides its high level of vitamin $A$, it is high also in vitamin $C$, that can help boost the immune system. Its supply of vitamin E, iron and folate may strengthen the immunity as well (Maggini et al 2007; Huijskens et al 2014 and Veldhoen and Ferreira, 2015). It is also good supply of fiber and potassium, which have been linked to heart health benefits (Milde et al 2007 and Vinceti et al 2016).

For that in view, it was aimed in this study to annexation such impressive health benefits possessed of pumpkin to mango drink in addition to a rich source of the essential electrolytes, namely ultrafiltered (UF) milk permeate en route to innovate a functional drink. 

fortified with pumpkin cubes en route to innovate a functional drink

\section{MATERIALS AND METHODS}

\section{Materials}

Mango fruits (Mangifira indica) were purchased from El-Obour market, El-Obour City, Qalyoubia Governorate, Egypt. Fresh pumpkin fruit (Cucurbita pepo) was obtained from "Hyper one" market, ElSheikh Zayed City, Giza Governorate, Egypt. Ultrafiltered milk permeate (UFMP) was obtained from Animal Production Research Institute, Agricultural Research Center, Giza, Egypt. Commercial grade granulated cane sugar produced by Sugar and Integrated Industries Co. at Hawamdia, Giza Governorate, Egypt. Other used ingredients; i.e., calcium chloride and sodium carboxy methyl cellulose (CMC) were obtained from El-Gomhouria Co. for Drugs and Medical Supplies, Cairo, Egypt.

\section{Experimental procedures}

\subsection{Preparation of mango pulp}

Mango fruits were washed and then peeled. Seeds were removed to get the mango pulp, which was blended to obtain a homogenous pulp. Thus, the pulp is ready for using as fresh as in the preparation of the drink.

\subsection{Preparation of cooked pumpkin cubes}

Pumpkin fruit (ca $4 \mathrm{~kg}$ ) was washed and cut into 2 halves to remove the seeds and peeled. The peeled pumpkin fruit was cut into small cubes of equal size $\left(\mathrm{ca}\right.$ one $\mathrm{cm}^{3}$ ) and cook in hot water at $90^{\circ} \mathrm{C}$ for $5 \mathrm{~min}$. Thereafter, cooked pumpkin cubes (CPC) were cooled to $\mathrm{ca} 4^{\circ} \mathrm{C}$.

2.3. Preparation of mango pulp drink partially replaced with cooked pumpkin cubes

Mango drink based on $14 \%$ pulp and $12 \%$ sucrose was made (the control). Mango pulp was replaced with cooked pumpkin cubes (CPC) at the level of 5,10 or $15 \%(\mathrm{~W} / \mathrm{W})$. Then $0.2 \% \mathrm{CMC}$, $0.015 \% \mathrm{CaCl}_{2}$ and $73.785 \%$ tap water were added for each one and well mixed. All drinks were heat treated at $90^{\circ} \mathrm{C}$ for $5 \mathrm{~min}$, filled into Pyrex glass bottles, air tightly closed and cooled to ca $4^{\circ} \mathrm{C}$, (Table, 1).

2.4. Preparation of mango pulp drink replaced with $10 \%$ cooked pumpkin cubes made using milk permeate instead of water with different levels

Drink based on $12.6 \%$ mango pulp, $1.4 \%$ CPC, $12 \%$ sucrose $0.2 \% \mathrm{CMC}, 0.015 \% \mathrm{CaCl}_{2}$ and $73.785 \%$ tap water was prepared (control). Then, the water was replaced with ultrafiltered milk permeate (MP) at the level of 25,50 or $75 \%$ and well mixed. All drinks were heat treated at $90^{\circ} \mathrm{C}$ for 5 min, filled into Pyrex glass bottles, air tightly closed and cooled to $\mathrm{ca} 4^{\circ} \mathrm{C}$, (Table, 2).

\section{Analytical methods}

Physiochemical analyses including moisture, total nitrogen, fat, fiber, Reducing sugars and ash contents were determined according to AOAC (2012). Carbohydrate content was calculated by difference. The total sugars content was determined according to phenol-sulphoric acid method as described by Charles (2010). Titratable acidity content was determined as citric acid according to the method of AOAC (2012). The pH value in milk was measured electrometrically using Lab. $\mathrm{pH}$ meter with a glass electrode, Hanna model 8417 digital $\mathrm{pH}$ meter at $20^{\circ} \mathrm{C}$ after calibrating with fresh $\mathrm{pH} 4.0$ and 7.0 standard buffers according to the methods of BSI (1989).

Sensory evaluation was carried out by ten panelists using 10 - hedonic scale for color, consistency, taste and overall acceptability (Meilgaard et al 2016).

Statistical analysis was performed according to SAS (1990) using General Linear Model (GLM) with main effect of treatments. Duncan's multiple range was used to separate among of three replicates at $P \leq 0.05$. 
Table 1. Recipe of mango pulp drink partially replaced with cooked pumpkin cubes

\begin{tabular}{|c|c|c|c|c|}
\hline \multirow{2}{*}{ Ingredient (g) } & \multicolumn{3}{|c|}{ Mango pulp replacement level with cooked pumpkin cubes (W/W) } \\
\cline { 2 - 4 } & $\begin{array}{c}\text { Nil } \\
\text { (Control) }\end{array}$ & $\mathbf{5 \%}$ & $\mathbf{1 0} \%$ & $\mathbf{1 5 \%}$ \\
\hline Mango pulp & 140 & 133 & 126 & 119 \\
Pumpkin cubes & - & 7 & 14 & 21 \\
Sucrose & 120 & 120 & 120 & 120 \\
CMC & 2 & 2 & 2 & 2 \\
Calcium chloride & 0.15 & 0.15 & 0.15 & 0.15 \\
Water & 737.85 & 737.85 & 737.85 & 737.85 \\
\hline Total & $\mathbf{1 0 0 0}$ & $\mathbf{1 0 0 0}$ & $\mathbf{1 0 0 0}$ & $\mathbf{1 0 0 0}$ \\
\hline
\end{tabular}

Table 2. Recipe of mango pulp drink replaced with $10 \%$ cooked pumpkin cubes made using ultrafiltered (UF) milk permeate instead of water with different levels

\begin{tabular}{|c|c|c|c|c|}
\hline \multirow{2}{*}{ Ingredient (g) } & \multicolumn{3}{|c|}{ Water replacement level with UF-milk permeate } \\
\cline { 2 - 5 } & $\begin{array}{c}\text { Nil } \\
\text { (Control) }\end{array}$ & $\mathbf{2 5 \%}$ & $\mathbf{5 0 \%}$ & $\mathbf{7 5 \%}$ \\
\hline Milk permeate & 0.00 & 184.46 & 368.93 & 553.39 \\
Water & 737.85 & 553.39 & 368.93 & 184.46 \\
Sucrose & 120 & 120 & 120 & 120 \\
Mango pulp & 126 & 126 & 126 & 126 \\
Pumpkin cubes & 14 & 14 & 14 & 14 \\
CMC & 2 & 2 & 2 & 2 \\
Calcium chloride & 0.15 & 0.15 & 0.15 & 0.15 \\
\hline Total & 1000 & 1000 & 1000 & 1000 \\
\hline
\end{tabular}


Utilization of ultrafiltered milk permeate as water substitute in mango drink fortified with pumpkin cubes en route to innovate a functional drink

\section{RESULTS AND DISCUSSION}

\section{1- Proximate composition of main ingredients}

The proximate chemical composition of main ingredients that used to fortify fruit dairy drink was given in Table (3). Cooked pumpkin cubes (CPC) had moisture, total nitrogen, fat, ash and fiber with $91.39,0.318,0.78,0.31$ and $1.35 \%$, respectively. These results of CPC are in coincidence with those found by Rizk (2016) and Abd El-Gaber (2018). The corresponding values that determined in mango pulp were $83.42,0.128,0.36,0.33$, and $1.5 \%$ respectively. While, those in milk permeate (MP) were, in order $94.32,0.021,0.00,0.15$ and $0.00 \%$. The UFMP composition agrees with those found by Fayed (1986) and El-Awamry (1990). By calculating the total carbohydrates data showed mango fruit contains 3.19 times higher than that of pumpkin one.

Table 3. Proximate chemical composition of main ingredients used for making mango drink

\begin{tabular}{|c|c|c|c|}
\hline \multirow{2}{*}{$\begin{array}{c}\text { Component } \\
(\%)\end{array}$} & $\begin{array}{c}\text { Mango } \\
\text { pulp }\end{array}$ & $\begin{array}{c}\text { Cooked } \\
\text { pumpkin } \\
\text { cubes }\end{array}$ & $\begin{array}{c}\text { Milk } \\
\text { permeate }\end{array}$ \\
\cline { 2 - 4 } Moisture & 83.42 & 91.39 & 94.32 \\
Total nitrogen & 0.128 & 0.318 & 0.021 \\
Fat & 0.36 & 0.78 & 0.00 \\
Ash & 0.33 & 0.31 & 0.15 \\
Fiber & 1.50 & 1.35 & 0.00 \\
Carbohydrates* & 13.59 & 4.26 & 5.40 \\
\hline
\end{tabular}

${ }^{*}$ Calculated by difference

2- Selection of the most preferred mango pulp replacement level with cooked pumpkin cubes

2.1- Physicochemical properties of mango pulp drink as replaced with cooked pumpkin cubes

Physicochemical properties of prepared mango drink as replaced with CPC were shown in Table (4). The mango drink contains $83-84 \%$ moisture along different replacing levels with CPC compared with control sample (83.36\%).

Total solids content took the opposite direction of moisture content. Moreover, once the CPC was added, at any level, both acidity and ash contents were significantly lowered. Meanwhile, reversible patterns were noticed regarding $\mathrm{pH}$ value, which exhibited proportional increase as the replacement level of mango pulp with CPC heightened. Total as well as reducing sugars contents of drink significantly diminished as the CPC level increased. It is may be due to the relatively lower carbohydrates content possessed CPC versus mango pulp (Table, 3).

\section{2- Sensory screening of mango drink as replaced with cooked pumpkin cubes}

Concerning the judging scores, the Figures listed in Table (5) show that, the drink color did not significantly influence by adding CPC up to $10 \%$, then the color score reduced when the replacement level increased. This could be due to that, unlike CPC, mango pulp was indeed, the sole source of the dissolved color present in the drink solution. The consistency score lowered significantly as the portion of CPC heightened. The participation of mango pulp in the drink consistency reduced in the presence of $5 \%$ CPC. The heavy distribution of CPC when added at the level of $10 \%$ restored the body weakness occurred due to the partial absence of mango pulp. But, the drink consistency became heavier when the replacement level increased to $15 \%$. Moreover, the drink suffered from some taste flatness in the case of $5 \%$ CPC, which improved again at the 10\% CPC and then messy taste was observed at the level of 15 $\%$ CPC.

The overall acceptance of $10 \%$ CPC - Mango drink was as good as the control. While, this criterion was low scored for the $5 \%$ and rather $15 \%$ $\mathrm{CPC}$ - mango drinks.

So, the forgoing organoleptic results led satisfactory to choose the mango drink replaced with $10 \%$ CPC for the following study as a control towards the partially utilization of milk permeate instead water.

3- Selection of the most preferred water replacement level with milk permeate

3.1- Physicochemical properties mango drink replaced with $10 \%$ cooked pumpkin cubes made using UF-milk permeate

Regarding the data displaying in Table (6) it could observe that, the moisture content of drink decreased and hence the total solids increased proportionally as the portion of UFMP instead of water raised. That is axiomatically due to the solids 
present in the milk permeate versus the water. Moreover, the water replacement with water up to $25 \%$ did not result in any significant effect on the acidity content nor the $\mathrm{pH}$ value of drink. There more, significant decrement in the acidity content and hence increment in the $\mathrm{pH}$ value of drink were occurred as the milk permeate portion rose than $25 \%$. Once the milk permeate was added at any level, the ash content of drink was significantly heightened. Similarly, significant ascending pattern in total and reducing sugars contents of drink were seen by increasing the milk permeate level. That could be attributed to lactose-induced the permeate solids. These findings agree with those reported by Rizk (2016).

Table 4. Physicochemical properties of mango drink as affected by replacing with cooked pumpkin cubes

\begin{tabular}{|c|c|c|c|c|}
\hline \multirow{2}{*}{ Parameter } & \multicolumn{4}{|c|}{ Mango pulp replacement level with cooked pumpkin cubes } \\
\hline & Nil (Control) & $5 \%$ & $10 \%$ & $15 \%$ \\
\hline Moisture (\%) & $83.36^{\mathrm{b}} \pm 1.30$ & $83.40^{\mathrm{b}} \pm 1.52$ & $83.95^{\mathrm{a}} \pm 1.41$ & $83.34^{\mathrm{b}} \pm 1.95$ \\
\hline Total solids (\%) & $16.64^{a} \pm 0.12$ & $16.60^{\mathrm{a}} \pm 0.11$ & $16.05^{\mathrm{b}} \pm 0.06$ & $16.66^{\mathrm{a}} \pm 0.10$ \\
\hline Acidity (\%) & $0.52^{\mathrm{a}} \pm 0.10$ & $0.41^{\mathrm{ab}} \pm 0.10$ & $0.34^{\mathrm{ab}} \pm 0.10$ & $0.25^{\mathrm{b}} \pm 0.10$ \\
\hline $\mathrm{pH}$ value & $4.58^{c} \pm 0.35$ & $4.69^{c} \pm 0.37$ & $4.90^{b} \pm 0.41$ & $5.18^{\mathrm{a}} \pm 0.43$ \\
\hline Ash (\%) & $0.19^{a} \pm 0.02$ & $0.14^{\mathrm{b}} \pm 0.02$ & $0.12^{b} \pm 0.02$ & $0.12^{b} \pm 0.01$ \\
\hline Total sugars (\%) & $15.24^{a} \pm 3.42$ & $14.82^{b} \pm 3.72$ & $14.50^{b} \pm 2.40$ & $13.74^{c} \pm 3.30$ \\
\hline Reducing sugars (\%) & $2.13^{a} \pm 1.02$ & $1.90^{b} \pm 1.14$ & $0.94^{c} \pm 1.54$ & $0.75^{d} \pm 1.33$ \\
\hline
\end{tabular}

Means $( \pm S D)$ with the same letter at any position did not significantly differ $(p>0.05)$.

Table 5. Panelist scores of mango drink as affected by replacing with cooked pumpkin cubes

\begin{tabular}{|c|c|c|c|c|}
\hline \multirow{2}{*}{ Sensory attribute } & \multicolumn{4}{|c|}{ Mango pulp replacement level with cooked pumpkin cubes } \\
\cline { 2 - 5 } (out of 10 point) & Nil & & & \\
(Control) & $5 \%$ & $10 \%$ & $15 \%$ \\
\hline Color & $9.40^{\mathrm{a}} \pm 0.70$ & $9.30^{\mathrm{a}} \pm 1.32$ & $9.20^{\mathrm{a}} \pm 0.52$ & $8.40^{\mathrm{b}} \pm 1.65$ \\
Consistency & $9.20^{\mathrm{a}} \pm 0.79$ & $9.00^{\mathrm{ab}} \pm 1.23$ & $8.80^{\mathrm{b}} \pm 0.82$ & $7.10^{\mathrm{c}} \pm 1.73$ \\
Taste & $8.50^{\mathrm{a}} \pm 1.27$ & $7.60^{\mathrm{c}} \pm 0.70$ & $8.20^{\mathrm{b}} \pm 1.23$ & $6.10^{\mathrm{d}} \pm 1.37$ \\
Overall acceptability & $9.50^{\mathrm{a}} \pm 0.53$ & $7.90^{\mathrm{b}} \pm 0.74$ & $9.40^{\mathrm{a}} \pm 0.52$ & $6.70^{\mathrm{c}} \pm 1.16$ \\
\hline
\end{tabular}

Means $( \pm S D)$ with the same letter at any position did not significantly differ $(p>0.05)$. 

fortified with pumpkin cubes en route to innovate a functional drink

Table 6. Physicochemical properties of drink of mango pulp replaced with $10 \%$ cooked pumpkin cubes made using milk permeate instead of water with different levels

\begin{tabular}{|c|c|c|c|c|}
\hline \multirow{2}{*}{ Parameter } & \multicolumn{4}{|c|}{ Water replacement level with milk permeate } \\
\cline { 2 - 5 } & $\begin{array}{c}\text { Nil } \\
\text { Control }\end{array}$ & $25 \%$ & $50 \%$ & $75 \%$ \\
\hline Moisture (\%) & $83.95^{\mathrm{a}} \pm 1.41$ & $82.97^{\mathrm{b}} \pm 1.43$ & $81.35^{\mathrm{c}} \pm 1.33$ & $80.77^{\mathrm{d}} \pm 1.11$ \\
Total solids (\%) & $16.05^{\mathrm{d}} \pm 0.06$ & $17.03^{\mathrm{c}} \pm 0.20$ & $18.65^{\mathrm{b}} \pm 0.31$ & $19.23^{\mathrm{a}} \pm 0.42$ \\
Acidity (\%) & $0.34^{\mathrm{a}} \pm 0.10$ & $0.29^{\mathrm{a}} \pm 0.14$ & $0.18^{\mathrm{b}} \pm 0.04$ & $0.13^{\mathrm{b}} \pm 0.05$ \\
pH value & $4.90^{\mathrm{b}} \pm 0.41$ & $5.18^{\mathrm{b}} \pm 0.43$ & $5.63^{\mathrm{a}} \pm 0.48$ & $5.74^{\mathrm{a}} \pm 0.50$ \\
Ash (\%) & $0.12^{\mathrm{b}} \pm 0.02$ & $0.18^{\mathrm{a}} \pm 0.06$ & $0.19^{\mathrm{a}} \pm 0.04$ & $0.20^{\mathrm{a}} \pm 0.05$ \\
\hline Total sugars (\%) & $14.50^{\mathrm{d}} \pm 1.40$ & $15.83^{\mathrm{c}} \pm 1.45$ & $16.70^{\mathrm{b}} \pm 1.14$ & $18.73^{\mathrm{a}} \pm 1.32$ \\
\hline Reducing sugars (\%) & $0.94^{\mathrm{d}} \pm 0.20$ & $2.33^{\mathrm{c}} \pm 0.40$ & $3.90^{\mathrm{b}} \pm 0.52$ & $5.28^{\mathrm{a}} \pm 0.77$ \\
\hline
\end{tabular}

Means $( \pm S D)$ with the same letter at any position did not significantly differ $(p>0.05)$.

3.2- Sensory quality of drink of mango drink replaced with $10 \%$ cooked pumpkin cubes made using UF-milk permeate

The organoleptic evaluation of mango pulp drink substituted with $10 \%$ CPC as a function of replacement level of water with milk permeate revealed that, although water replacement levels of
25 and even $50 \%$ milk permeate did not produce satisfactory sensory acceptance, the highest replacement level $(75 \%)$ resulting a drink as good as the control in the criterion of color as well as the overall acceptability and rather improve both criteria of consistency and taste (Table, 7). Similar observations were reported by El-Kholy and Abbas (2015) and Rizk (2016).

Table 7. Panelist scores of mango pulp drink replaced with $10 \%$ cooked pumpkin cubes made using UF-milk permeate

\begin{tabular}{|c|c|c|c|c|}
\hline \multirow{2}{*}{$\begin{array}{c}\text { Sensory attribute } \\
\text { (out of } 10 \text { point) }\end{array}$} & \multicolumn{4}{|c|}{ Water replacement level with milk permeate } \\
\cline { 2 - 5 } & $\begin{array}{c}\text { Nil } \\
\text { (Control) }\end{array}$ & $25 \%$ & $50 \%$ & $75 \%$ \\
\hline Color & $9.60^{\mathrm{a}} \pm 0.52$ & $8.40^{\mathrm{c}} \pm 1.17$ & $8.50^{\mathrm{b}} \pm 1.18$ & $9.30^{\mathrm{a}} \pm 0.67$ \\
Consistency & $9.00^{\mathrm{b}} \pm 0.82$ & $8.50^{\mathrm{c}} \pm 0.85$ & $8.40^{\mathrm{c}} \pm 0.84$ & $9.40^{\mathrm{a}} \pm 0.70$ \\
Taste & $8.20^{\mathrm{bc}} \pm 1.23$ & $8.30^{\mathrm{bc}} \pm 0.95$ & $8.30^{\mathrm{bc}} \pm 0.95$ & $9.40^{\mathrm{a}} \pm 0.70$ \\
Overall acceptability & $9.40^{\mathrm{a}} \pm 0.52$ & $8.00^{\mathrm{c}} \pm 0.67$ & $8.60^{\mathrm{b}} \pm 0.97$ & $9.20^{\mathrm{a}} \pm 0.42$ \\
\hline
\end{tabular}

Means $( \pm S D)$ with the same letter at any position did not significantly differ $(p>0.05)$.

\section{CONCLUSION}

Finally, the forgoing results led satisfactory to conclude that, it could successfully made a drink that meets the intended health purposes based on the substitution of $10 \%$ of mango pulp with cooked cubes of pumpkin of many impressive health benefits as well as utilization of UF milk permeate as a source of the essential electrolytes instead of $75 \%$ of required water en route to innovate a functional drink. 


\section{REFERENCES}

Abd El-Gaber H.K. 2018. Development and assessment of some chicken products as functional foods. M.Sc. Thesis, Fac. of Agric., Ain Shams Univ., Egypt. pp. 41-64.

Abd El-Khair A.A. 2009. Formulation of milk permeate for utilization as electrolyte beverages. Australian J. Basic and Applied Sci., 3, 572578.

AOAC 2012. Association of Official Analytical Chemists. Official methods of analysis of AOAC International, $19^{\text {th }}$ ed., Benjamin Franklin, Washington D.C., USA.

Beucler A., Drake M. and Foegeding M.A. 2005. Design of a beverage from whey permeate. J. Food Sci., 70, S277-S285.

BSI 1990. British Standards Institution. Testing aggregates. General requirements for apparatus and calibration. BS 812: Part 100, BSI, London, UK.

Charles C. 2010. Phenol-sulfuric acid method for total carbohydrates. In: Food Analysis Laboratory Manual (Nielsen, S.S., Ed.), $2^{\text {nd }}$ Ed. Chap. 6, pp. 48-53. Springer, IN, USA.

Dreher, D and Junod A.F. 1996. Role of oxygen free radicals in cancer development. Eur. J. Cancer, 32A, 30-38.

Eisenhauer B., Natoli S., Liew G. and Flood V.M. 2017. Lutein and zeaxanthin-food sources, bioavailability and dietary variety in age-related macular degeneration protection. Nutrients, 9, 9-12.

El-Kholy A.M. and Abbas F.M. 2015. Using of pumpkin (Cucurbita moschata) in making healthy functional ice milk. Ismailia J. Dairy Sci. \& Technol.; Suez Canal Univ., 2, 1-6.

El-Awamry Z.K. 1990. Reduction of pollution load in Egyptian dairies by utilization of their byproducts. M.Sc. Thesis, Institute of Environmental Studies, Ain Shams Univ., Cairo, Egypt, pp. 56-66.

EOSQ 2017. Egyptian Organization for Standardization and Quality. Non-carbonated sweetened drinks, fruit drinks and artificial fruit flavored drinks. Egyptian Standards (ES): 1602/2017.

Fayed A.E. 1986. Protein fortification of some dairy products. Ph.D. Thesis, Fac. of Agric., Ain Shams Univ., Cairo, Egypt, pp. 40-50.

Fitzpatrick, J., Ahrens M. and Smith S. 2001. Effect of manganese on Lactobacillus casei fermentation to produce lactic acid from whey permeate. Process Biochem., 36, 671-675.
Gong L., Paris H.S., Nee M.H., Stift G., Pachner M., Vollmann J. and Lelley T. 2012. Genetic relationships and evolution in Cucurbita pepo (pumpkin, squash, gourd) as revealed by simple sequence repeat polymorphisms. Theor. Appl. Genet., 124, 875-891.

Hattem H.E., Elham H., Abouel Einin and Mehanaan N.M. 2011. Utilization of milk permeate in manufacture of sports drinks. J. Brewing and Distilling, 2, 24-27.

Hu F., Wang Y. B., Zhang W., Liang J., Lin C., Li D., Wang F., Pang D. and Zhao Y. 2012. Carotenoids and breast cancer risk: A metaanalysis and meta-regression. Breast Cancer Res. Treat., 131, 239-253.

Huijskens M.J., Walczak M., Koller N., Briedé J.J., Senden-Gijsbers B.L., Schnijderberg M.C., Bos G.M. and Germeraad W.T. 2014. Technical advance: Ascorbic acid induces development of double-positive $\mathrm{T}$ cells from human hematopoietic stem cells in the absence of stromal cells. J. Leukoc. Biol., 96, 1165-1175.

Johnson E.J. 2002. The role of carotenoids in human health. Nutr. Clin. Care, 5, 56-65.

Khansari N., Shakiba Y. and Mahmoudi M. 2009. Chronic inflammation and oxidative stress as a major cause of age-related diseases and cancer. Recent Pat. Inflamm. Allergy Drug Discov., 3, 73-80.

Maggini S., Wintergerst E.S., Beveridge S. and Hornig D.H. 2007. Selected vitamins and trace elements support immune function by strengthening epithelial barriers and cellular and humoral immune responses. Br. J. Nutr., 98, Suppl 1, S29-S35.

McEwan J.A. and Colwill J.S. 1996. The sensory assessment of the thirst-quenching characteristics of drinks. Food Quality and Preference, 7, 101-111.

Meilgaard M., Civille G.V. and Carr B.T. 2016. Sensory Evaluations Techniques. Boca Raton: CRC. Press, pp. 43-57.

Milde J., Elstner E.F. and Grassmann J. 2007. Synergistic effects of phenolics and carotenoids on human low-density lipoprotein oxidation. Mol. Nutr. Food Res., 51, 956-961.

Neves M.F., Trombin V.G., Lopes F.F., Kalaki R. and Milan P. 2011. Definition of juice, nectar and still drink. In: The Orange Juice Business. A Brazilian Perspective. Wageningen Academic Publ., the Netherlands. 117 p.

Pullar J.M., Carr A.C. and Vissers M.C.M. 2017. The Roles of vitamin C in skin health. Nutrients, pp. 9-12. 

fortified with pumpkin cubes en route to innovate a functional drink

Rizk A.E. 2016. Study of production functional beverages of milk permeate fortified with fruit and herbs. Middle East J. Applied Sci., 6, 155-161.

Roberts R.L., Green J. and Lewis B. 2009. Lutein and zeaxanthin in eye and skin health. Clin. Dermatol., 27, 195-201.

SAS 1990. Statistical Analysis System. SAS user's guide. Statistics. SAS Inst. Inc. $4^{\text {th }} \mathrm{Ed}$, Cary, NC, USA.

Stahl W. and Sies H. 2012. $\beta$-Carotene and other carotenoids in protection from sunlight. Amer. J. Clin. Nutr., 96, 1179S-1184S.

Veldhoen M. and Ferreira C. 2015. Influence of nutrient-derived metabolites on lymphocyte immunity. Nat. Med., 21, 709-718.

Vinceti M., Filippini T., Crippa A., de Sesmaisons A., Wise L.A. and Orsini N. 2016. Metaanalysis of potassium intake and the risk of stroke. J. Amer. Heart Assoc., 5, e004210. Doi://10.1161/JAHA.116.004210.

Wang A., Han J., Jiang Y. and Zhang D. 2014. Association of vitamin $A$ and $\beta$-carotene with risk for age-related cataract: $A$ meta-analysis. Nutr., 30,1113-1121.

Wang Z.X., Dong P.C., Sun T.T., Xu X.R., Ma L., Huang Y.M. and Lin X.M. 2011. Comparison of lutein, zeaxanthin and $\beta$-carotene level in raw and cooked foods consumed in Beijing. Zhonghua Yu Fang Yi Xue Za Zhi., 45, 64-67.

Williams L.A. 2001. Trend setting drinks: The new developments and trends that will be shaping their industry in the years to come. The World of Food Ingredients, 50, 45-48.

Zhou Y., Wang T., Meng Q. and Zhai S. 2016. Association of carotenoids with risk of gastric cancer: A meta-analysis. Clin. Nutr., 35, 109116. 


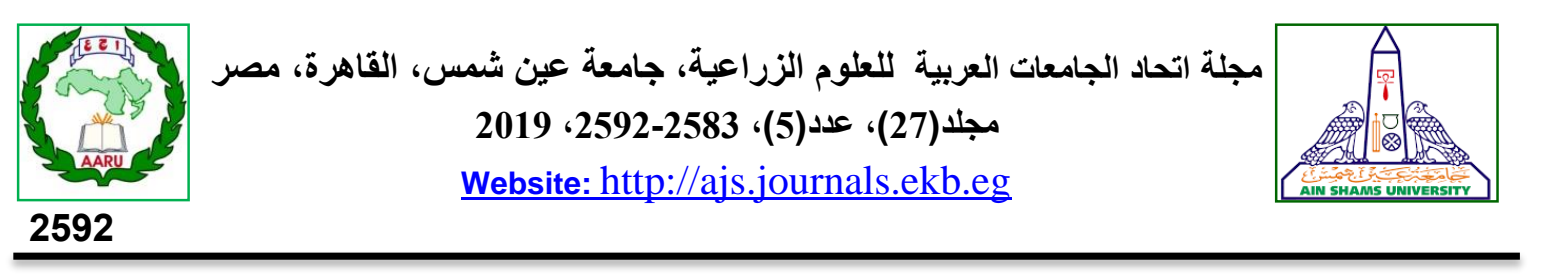

الإستفادة من راشتح اللبن الناتج من الترشيح الفائق كبديل للماء المستخدم الإبتكار مشروب

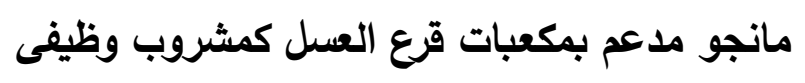

[205]

\author{
مروة ابراهيم عيد" - عاطف السيد فايد - محمد فرج خلاف - محمد يوسف ابو النجا

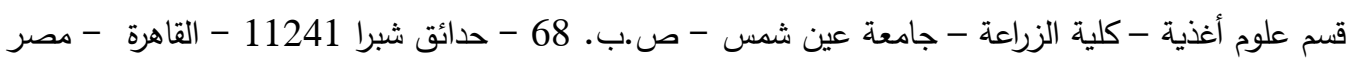

*Corresponding author: marwaibrahim910@gmail.com

Received 4 December, 2019 Accepted 19 January, 2020

ورقم الأس الهيدروجينى وعلى العكس من ذلك كان

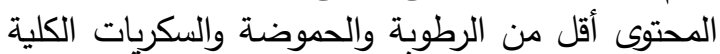

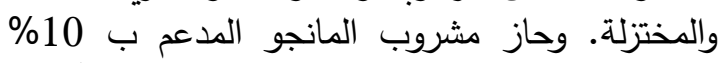

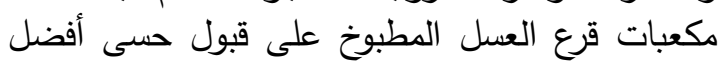
من عينة الدقارنة من ناحية اللون والقبول العام بينما

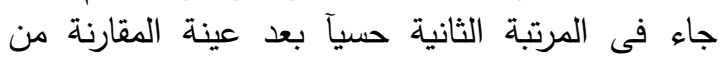

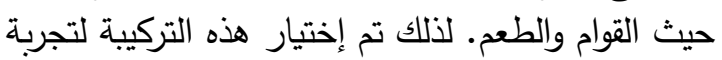

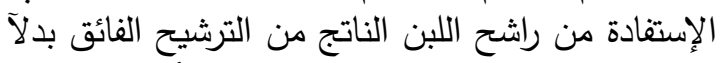
من الماء فى إنتاج المشروب. ولقد أكدات الندان النتائج

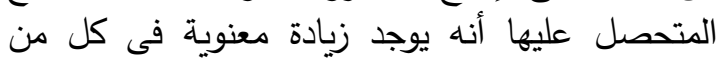

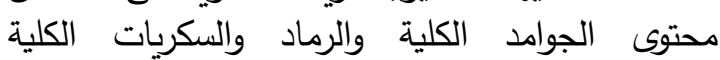

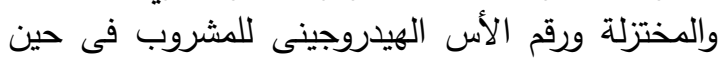

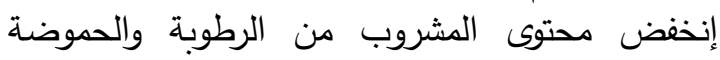

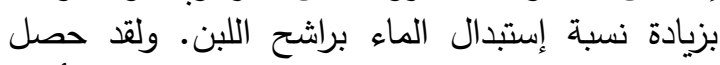

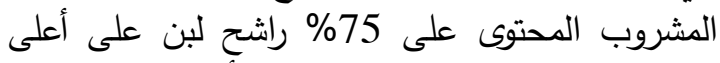

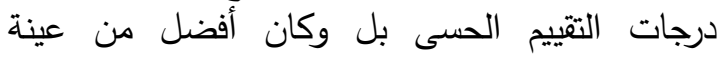

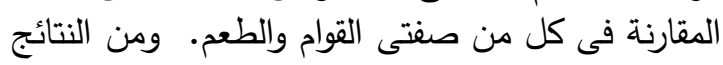

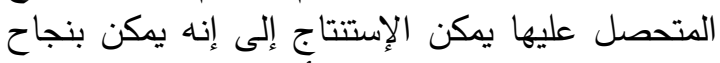

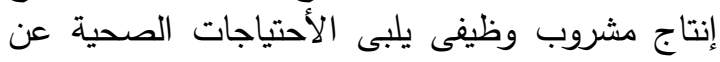

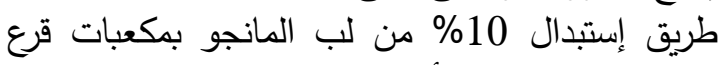
العسل المطبوخة بالأضافة إلى إستخدام راشح الثيات اللبن

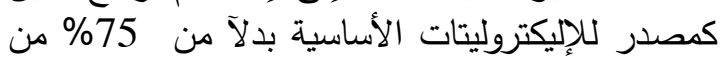

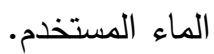

الكلمات الدالة: السكريات والجوامد الكلية، الحموضة، الرماد، الخواص الحسية، المشروبات الوظيفية

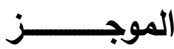

تهدف هذه الدراسة للإِتفادة من الفوائد الصحية

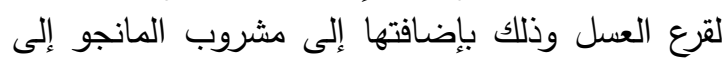

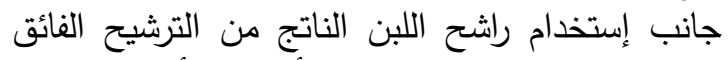
كصدر رئيسى لإليكتروليتات الأساسية لأنتاج مشروب النقان

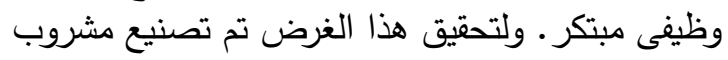

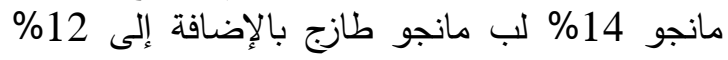
سكروز (كمعاملة مقارنة). وتم إستبدال لب الماند المانجو

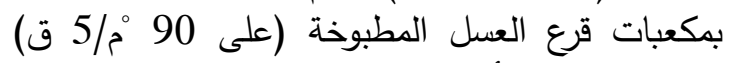

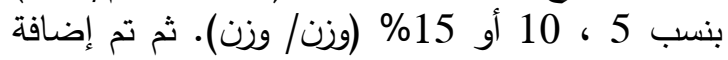

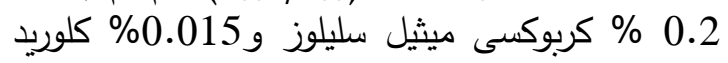

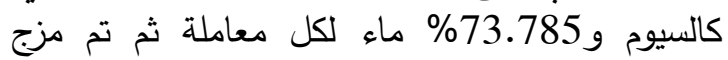
الخليط جيدآ. ومن ناحية أخرى إحتوت معاملة المقارنة على 12.6\% لب مانجو و1.4\% مكعبآ مكبات قرع العسل

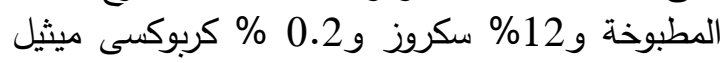

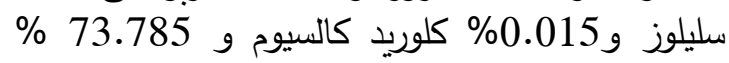

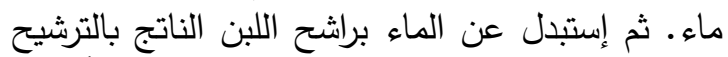

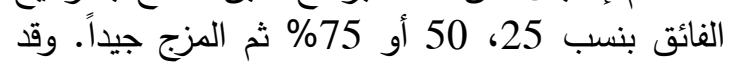

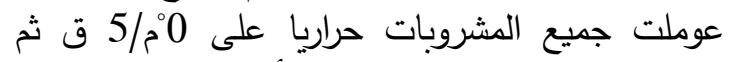
التعبئة فى زجاجات من البيركس وأحكم غلقها ثم التبريد

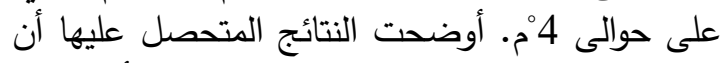

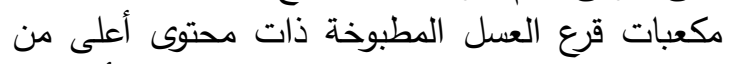
كل من الرطوبة والنيتروجين الكلى ومحتوى أقلى من ألى من الكنات الكربوهيدرات بالكقارنة بلب المانجو . لذلك فإن إستبدال

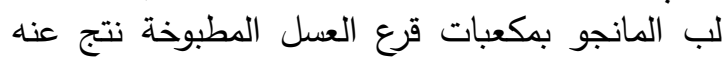
مشروب مرتفع معنوياً فى محتواه من الجوامد الكلية لعند 